\title{
Causality Analysis of Producer Price Index (PPI) and Consumer Price Index (CPI) in Indonesia
}

\author{
Debby Anggraeni ${ }^{1}$, Tony Irawan ${ }^{2}$ \\ ${ }^{1}$ Central Bureau of Statistics
}

Jl. Dr. Sutomo 6-8, Pasar Baru, Jakarta Pusat, DKI Jakarta 10710, Indonesia

${ }^{2}$ Department of Economics, Bogor Agricultural University

Jl. Kamper, Kampus IPB Darmaga, Gedung FEM Lt. II, Bogor 16680

[received: 1 July 2018 - revised 20 July 2018 - available online: 1 August 2018]

\begin{abstract}
ABSTRAK
Penelitian ini bertujuan untuk melihat hubungan antara inflasi indeks harga produsen (IHP) dan inflasi indeks harga konsumen (IHK) di Indonesia baik secara umum dan untuk setiap komoditas, selain itu, untuk mengidentifikasi apakah inflasi IHP dapat menjadi indikator utama untuk inflasi IHK atau sebaliknya. Penelitian ini menggunakan Granger causality dengan model VAR untuk seri data bulanan dari Januari 2010 hingga Agustus 2016. Hasil penelitian secara umum telah menunjukkan bahwa ada hubungan searah antara inflasi IHP dan inflasi IHK, selain itu, adanya hubungan dua arah dari inflasi IHP terhadap inflasi IHK untuk kelompok bahan makanan, selanjutnya adanya hubungan searah dari Inflasi IHK terhadap IHP untuk kelompok pakaian, dan tidak ada hubungan kausalitas antara inflasi IHP dan inflasi IHK untuk kelompok makanan jadi, minuman, rokok, dan tembakau.
\end{abstract}

Kata Kunci: Granger causality, Indeks Harga Konsumen, Indeks Harga Produsen, VAR

\begin{abstract}
This study aims to investigate the relationship between PPI inflation and CPI inflation in Indonesia both in general and for each group of commodity, and to identify whether PPI inflation can be a leading indicator for CPI inflation or vice versa. This study employs Granger causality based on VAR model for monthly data series from January 2010 until August 2016. The results show that there are unidirectional relationship between PPI inflation and CPI inflation generally, bidirectional relationship from PPI inflation to CPI inflation for foodstuffs group, unidirectional from CPI inflation to PPI inflation for clothing group, and no causality between PPI inflation and CPI inflation for processed food, beverage, cigarette, and tobacco group.
\end{abstract}

Keywords: Granger causality, producer price index, consumer price index, VAR

JEL classification: E31, C22 


\section{INTRODUCTION}

The price index is an instrument used to measure price changes from one period to another. Price changes at producer and consumer level can be evaluated through the calculation of the price index, ie Producer Price Index (PPI) and Consumer Price Index (CPI). PPI measures price changes received by domestic producers for the goods and services they produce, so it is used to measure the price level that occurs at the producer level, while CPI is composed of the price of goods and services consumed by the public, and it is an indicator used to measure inflation (BPS 2015).

There are two approaches in looking at the relationship between PPI and CPI, namely the approach of supply and demand. On the supply side, changes in raw materials prices affect the price change of intermediate and final products. As a result, it will affect the consumer prices (Rogers in Yin and Xuan 2013). Therefore, PPI affects CPI. So, if there is a shock to the producer price, it will affect the consumer price, consequently PPI will affect CPI.

On the demand side, changes in demand in the final products will affect the change in input prices as production cost since the producer's price actually covers the overall cost of production determined by the pull of demand that affects resource costs because it depends on consumer prices (Colclough and Lange 1982). So that, shocks to consumer prices will affect the producer prices, consequently CPI affects PPI.

The relationship between PPI and CPI is still a controversial issue in empirical studies. There are 3 (three) types of relationships that can be inferred from previous studies, namely one-way relationship (unidirectional), bidirectional relationship, and no relationship (Akcay, 2011). Studies on the relationship between PPI and CPI have been conducted in different countries with different results.
Ghazali et al. (2008) found that there is a long-term relationship between PPI and CPI, as well as the PPI's one-way relationship to CPI. Caporale et al. (2012) also found a one-way relationship of PPI to CPI in France and Denmark, a two-way relationship for Italy, and no relationship between PPI and CPI for Canadian case studies using Toda and Yamamoto (1995) tests. The unidirectional relationship of CPI to PPI in the US was found by Colclough and Lange (1982) using the Granger causality test. While Clark (1995) and Blomberg and Haris (1995) found that PPI does not significantly affect CPI in the future.

The relationship between PPI and CPI is an important issue for policy makers. If producer prices affect consumer prices, the information on producer prices can provide valuable predictions about consumer prices and policy makers can identify the cost-push shocks that can be used to forecast consumer price inflation (Tiwari 2012). Similarly, if consumer prices affect producer prices, the information on consumer prices can provide valuable predictions about producer prices and policy makers can identify the demand-pull shocks that can be used to forecast producer price inflation.

Inflation can be interpreted as an increase in the price level of goods in general (Mankiw 2006). Inflation is one of the most anticipated indicators to measure overall economic welfare. For the general public, inflation affects welfare because it affects purchasing power; and for the business world, the rate of inflation is an important factor in making decisions. Therefore, inflation has always been a concern of the government in formulating and implementing economic policies for the improvement of people's welfare (Utari et al., 2015).

Inflation is one of the important indicators in an economy that needs to be maintained its stability. According to Galodikwe (2014), inflation can weigh the 
cost of real economic output, so the price mechanism is difficult to use as a tool for efficient allocation of resources. The cost may be higher for developing countries than developed countries because inflation in developing countries is still relatively high compared to developed countries, so for countries whose incomes are still low trying to avoid the cost of rising prices and inflation including other changes, such as interest rates. It is important to see which inflation has an effect on the economy so as to clarify policy makers to mitigate the negative effects of the economy and the welfare costs of rising inflation (Chowdury, 2014).

Economists argue that PPI can be used as an important indicator in predicting consumer inflation in the future, as changes in prices paid by producers (cost changes) can lead to a change in the price paid by consumers, so it is important to look at the relationships of both indices (Galodikwe, 2014).

As noted above, the relationship between PPI and CPI is still a controversial issue, as there are also international studies that find the fact that the relationship between PPI and CPI is weak, such as Clark (1995) and Blomberg and Haris (1995) who found that PPI do not significantly affect the CPI in the future. In addition, during 2007-2009, 24 central bank publications were found, of which only 19 mentioned the PPI, and only 6 referenced the PPI as an indicator of inflation (Sidaoui et al. 2009).

Research on whether there is a relationship between PPI and CPI in Indonesia has been done by Yin and Xuan (2013) who examine the relationship between PPI and CPI in some countries including Indonesia. The study used PPI and CPI monthly data from 1980 to 2012 from International Financial Statistics (IFS). The PPI data used in the study is the data of the Big Trade Price Index (PPIB) instead of the Producer Price Index (PPI) data, as the PPI in Indonesia is only published in October 2013 with the data series starting in 2010.

Studies on the relationship between PPI and CPI have been conducted in many countries, but not many countries see the relationship between PPI and CPI based on commodity groups from each index. So this study tries to elaborate the relationship between PPI and CPI both in general, and for each commodity group, where the determination of this commodity group is based on identical commodities between the two commodity packages composing the index.

Based on the description above, the formulation of the problem that can be stated is how the causality relationship between PPI inflation and CPI inflation both in general and for each group, and whether the PPI can be a leading indicator for the CPI or vice versa?

\section{THEORETICAL AND EMPIRICAL FRAMEWORK}

\section{The Relationship between PPI and CPI}

In looking at the relationship between PPI and CPI, there are 2 (two) different approaches namely the supply and demand approach. On the supply side, PPI and CPI are linked by the production chain, where raw materials are used as inputs in the production of intermediate products which will be used in the production of final products. Changes in the price of raw materials will affect the price of intermediate products and final products that ultimately affect the consumer prices (Clark 1995). On the demand side, according to Colclough and Lange (1982), changes in demand for consumer goods affect input costs-production costs. Production costs reflect the opportunity cost of intermediate products and resources which will reflect the demand for final products and services (Caporale et al., 2012). 
Cushing and McGarvey (1990) assumed that demand for primary goods depends on future consumer price expectations. This assumption indicates that current demand and expectations of current demand in the past determine the consumer prices, and future demand expectations determine the producer prices. Demand for the final products has an impact on input prices. Therefore, CPI affects PPI.

Clark (1995) stated that the production chains linking PPI and CPI are weak. PPI changes can sometimes predict CPI changes but fail to systematically predict. Ghazali et al. (2008) in Malaysia, found that there is a long-term relationship between CPI and PPI, and there is a oneway relationship from PPI to CPI. In Mexico, it was found that PPI has an important relationship in predicting CPI inflation (Sidaoui et al., 2009). Galodikwe (2014) found a positive relationship between PPI and CPI in South Africa, which means that changes to PPI can significantly affect CPI changes.

According to the study conducted by Akcay (2011) and Tiwari (2012), there are 4 (four) possible relationships between PPI and CPI. There is no relationship, two-way relationship, one-way relationship of PPI to CPI, and one-way relationship of CPI to PPI.

The scope between PPI and CPI is different which lies in price, weighing, compilation method, and base year. To overcome these differences, researchers used changes in both indices and inflation values to see the relationship between PPI and CPI. In addition, the coverage of commodity groups between PPI and CPI is also different. PPI covers only 3 (three) major sectors namely agriculture, mining and quarrying, and processing industries. While CPI is grouped into seven groups, namely i) foodstuffs; ii) processed food, beverages, cigarettes, and tobacco; iii) housing, water, electricity, gas and fuel; iv) clothing; v) health; vi) education, recreation, and sport; and vii) transportation, communications and financial services (BPS 2015). So to adjust between PPI and CPI, as well as to see which groups have the greatest influence on inflation, we formed a new group on PPI containing commodities identical to CPI. The adjustable groups are foodstuffs, processed food, beverages, cigarettes, and tobacco, and clothing groups.

\section{Previous Studies}

Research on causality relationship between producer price index and consumer price index has been done in many countries. Among them, Akcay (2011) examined the causal relationship between PPI and CPI for 5 (five) countries in Europe using monthly data (processed) from August 1995 to December 2007. His research resulted in a one-way causal relationship between PPI and CPI in Finland and France, and there is a two-way / mutually influential relationship between the two indices in Germany. For the Netherlands and Sweden, no significant relationship was found.

Research by Ulke and Ergun (2013) resulted in a long-term one-way relationship of CPI to PPI in Turkey and a linear one-way long-term causality relationship between the variables. While the results of Granger causality does not indicate a short-term causality relationship. In Mexico, it was found that PPI has an important relationship in predicting CPI inflation (Sidaoui et al., 2009).

Another study by Tiwari and Shahbaz (2010) which examined the causality relationship between PPI and CPI showing the results that the variables cointegrated over the long term, indicating that the variables would change together. In his research also found that there is a two-way causal relationship between PPI and CPI both in the short and long term. Furthermore, it is found in forecasting analysis that in India, PPI can be an early indicator for CPI, which means that PPI is 
determined by market forces and become leading indicator for consumer price and inflation.

Clark (1995), Blomberg and Haris (1995) found that PPIs do not significantly affect CPI in the future. Clark (1995) pointed out that the production chains that link PPI and CPI are weak. PPI changes can sometimes predict CPI changes but fail to systematically predict them.

Yin and Xuan (2013) examined the cointegration relationship between PPI and CPI by using Granger causality analysis. Based on the study, it is found that there is a two-way relationship in the countries of Canada, Denmark, Indonesia, Japan, Pakistan and Uruguay, while in Spain, it is found that there is a one-way relationship from CPI to PPI. In Indonesia, we have not found any research on the causality relationship between producer price index and consumer price index, so this becomes a new research in Indonesia.

\section{Empirical Framework}

There are 2 (two) approaches in looking at the relationship between PPI and CPI, namely supply side and demand side (Akcay 2011). On the supply side, changes in raw product prices affect the price change of intermediate and final products, as a result, it will affect the consumer prices (Rogers in Yin and Xuan 2013). On the demand side, changes in demand in the final products will affect the change in input prices as production costs, since the producer's price actually covers the overall cost of production determined by the pull of demand that affects resource costs because it depends on consumer prices (Colclough and Lange 1982). So that, shocks to consumer prices will affect the producer price, consequently CPI affect PPI.

This study will examine whether there is a causal relationship between PPI and CPI and whether PPI can be a leading indicator for CPI or vice versa. The flow of thought that will be used in this research can be seen in Appendix 1.

\section{RESEARCH METHOD}

The data used in this research is secondary data in the form of time series. The PPI and CPI data and their seven groups are obtained from BPS. The data used is monthly data from January 2010 to August 2016. The analysis method used in this study is VAR analysis with Granger causality test. VAR analysis is used to see the causality relationship between PPI inflation and CPI inflation both in general, and for each commodity group.

The VAR model assumes that all economic variables are interdependent with others. Enders (2004) explained when the researcher does not have the certainty to determine that a variable is exogenous, then an expansion of natural displacement function analysis will treat each variable symmetrically. Based on previous explanation and previous research, it is assumed that there is causality relation between each variable, so the equation estimation using Vector Auto Regression (VAR) from the variables used in this research can be written as follows:

The relationship between general PPI and general CPI

a) IHP_umum ${ }_{t}=\beta_{10}+$

$\sum_{i=1}^{p} \beta_{11} I_{\text {IHP_umum }}-i+$

$\sum_{i=1}^{p} \alpha_{11} I_{\text {IHK_umum }}+i+\varepsilon_{t}$

IHK_umum $_{t}=\beta_{10}+$

$\sum_{i=1}^{p} \beta_{11} I H K_{-}$umum $_{t-i}+$

$\sum_{i=1}^{p} \alpha_{11} I_{\text {IHP_umum }}-i+\varepsilon_{t}$

b) The relationship between PPI of Foodstuffs and CPI of Foodstuffs

IHP_BM $M_{t}=\beta_{10}+$

$\sum_{i=1}^{p} \beta_{11} I H P_{-} B M_{t-i}+$

$\sum_{i=1}^{p} \alpha_{11} I H K_{-} B M_{t-i}+\varepsilon_{t}$

$I H K_{-} B M_{t}=\beta_{10}+$

$\sum_{i=1}^{p} \beta_{11} I H K_{-} B M_{t-i}+$

$\sum_{i=1}^{p} \alpha_{11} I H P_{-} B M_{t-i}+\varepsilon_{t}$

c) The relationship between PPI of Processed food, Beverages, Cigarettes 
and Tobacco and CPI of Processed food, Beverages, Cigarettes and Tobacco.

$I H P_{-} M M R T_{t}=\beta_{10}+$

$\sum_{i=1}^{p} \beta_{11} I H P_{-} M M R T_{t-i}+$

$\sum_{i=1}^{p} \alpha_{11} I H K_{-} M M R T_{t-i}+\varepsilon_{t}$

$I H K_{-} M M R T_{t}=\beta_{10}+$

$\sum_{i=1}^{p} \beta_{11} I H K_{-} M M R T_{t-i}+$

$\sum_{i=1}^{p} \alpha_{11} I H P_{-} M M R T_{t-i}+\varepsilon_{t}$

d) The relationship between PPI of

Clothing and CPI of Clothing

IHP_SDG $G_{t}=\beta_{10}+$

$\sum_{i=1}^{p} \beta_{11} I H P_{-} S D G_{t-i}+$

$\sum_{i=1}^{p} \alpha_{11} I H K \_S D G_{t-i}+\varepsilon_{t}$

$$
\begin{aligned}
& I H K_{-} S D G_{t}=\beta_{10}+ \\
& \sum_{i=1}^{p} \beta_{11} I H K_{-} S D G_{t-i}+ \\
& \sum_{i=1}^{p} \alpha_{11} I H P_{-} S D G_{t-i}+\varepsilon_{t}
\end{aligned}
$$

Where each variable is defined as general PPI inflation (PPI_UMUM), general CPI inflation (CPI_UMUM), PPI_BM inflation, foodstuffs CPI inflation (CPI_BM), PPI inflation of processed food, beverage, cigarette and tobacco (PPI_MMRT), CPI inflation of processed food, beverages, cigarettes and tobacco (CPI_MMRT), PPI Inflation of clothing (PPI_SDG), and CPI Inflation of clothing (CPI_SDG).

\section{RESULT AND DISCUSSION}

\section{Stationarity Test}

The first stage performed in VAR analysis before analyzing the model is to test the stationarity of the data for each variable used because most of the time series data has a unit root. The test is performed on each variable to be included in the model and the data entered is in the form of change of value of each index (inflation value). Test results of all variables at the level using Augmented Dicky Fuller (ADF) test are presented in the following table.

Table 1 Augmented Dickey Fuller Unit Root Test

\begin{tabular}{lccc}
\hline \multicolumn{1}{c}{ Variable } & Level & Probability & Description \\
\hline CPI_UMUM & -8.2429 & 0.0000 & Stationary \\
CPI-BM & -8.541 & 0.0000 & Stationary \\
CPI_MMRT & -6.5684 & 0.0000 & Stationary \\
CPI_SDG & -6.6667 & 0.0000 & Stationary \\
PPI_UMUM & -6.3716 & 0.0000 & Stationary \\
PPI_BM & -3.8252 & 0.0043 & Stationary \\
PPI_MMRT & -8.6084 & 0.0000 & Stationary \\
PPI_SDG & -5.474 & 0.0000 & Stationary \\
\hline
\end{tabular}

Source: BPS (processed)

\section{Lag Optimal Test}

Optimal lag determination becomes very important in VAR because the independent variable used is the lag of the endogenous variable. To obtain optimal lag, it can be used Akaike Information Criterion (AIC), Schwarz Information Criterion (SC) and Hannan-Quinn Information Criterion (HQ). The size of the selected lag is the lag that produces the smallest AIC, SC or HQ. Lag length selection is important because it can affect the acceptance and rejection of the null hypothesis, resulting in estimation bias and can produce inaccurate predictions. The optimal lag length selection in the var model is mainly to avoid the occurrence of serial correlation between error term with endogenous variable in the model which can cause the estimator to be inconsistent. The longer the lag used will reduce the degree of freedom and the amount of observation, whereas too short lag will produce wrong specification (Gujarati, 2009). 
Table 2 Lag Optimum

\begin{tabular}{ccccc}
\hline & \multicolumn{4}{c}{ Akaike Information Criterion (AIC) } \\
\cline { 2 - 5 } Lag & $\begin{array}{c}\text { PPI-CPI } \\
(\text { Umum) }\end{array}$ & $\begin{array}{c}\text { PPI-CPI } \\
(\mathrm{BM})\end{array}$ & $\begin{array}{c}\text { PPI-CPI } \\
(\text { MMRT) }\end{array}$ & $\begin{array}{c}\text { PPI-CPI } \\
(\text { SDG) }\end{array}$ \\
\hline 0 & 3.562188 & 6.712853 & $\left.\mathbf{1 . 3 6 3 5 8 6}^{*}\right)$ & 5.806328 \\
1 & 3.491104 & 6.610881 & 1.396200 & 5.605902 \\
2 & 3.329901 & 6.228455 & 1.476111 & 5.588739 \\
3 & 3.149926 & $\mathbf{6 . 1 8 0 3 5 8 * )}^{*}$ & 1.574220 & $\mathbf{5 . 5 3 5 8 4 9 *})$ \\
4 & 3.221414 & 6.241006 & 1.667303 & 5.556029 \\
5 & 3.187176 & 6.266973 & 1.649211 & 5.649708 \\
6 & $\left.\mathbf{3 . 1 3 4 6 4 6}^{*}\right)$ & 6.216038 & 1.660414 & 5.699709 \\
7 & 3.220110 & 6.196306 & 1.768988 & 5.738978 \\
\hline
\end{tabular}

*) The smallest AIC value

\section{Impulse Response Function (IRF) Analysis}

The impulse response function describes the rate of shock of one variable to another variable over a period of time. So it can be seen the effect of the shock of a variable on another variable until the influence is lost or return to the point of balance. With impulse response, we can track the response of endogenous variables within the VAR system due to shocks or changes in the interference variable / $\varepsilon$ (Widarjono 2016).

Based on IRF results above, it can be seen that generally when there is a good shock on consumer price inflation and producer price inflation, the response from producer price inflation and consumer price inflation only lasts about seven months, then gradually disappears. In the foodstuffs group, response from PPI inflation and CPI inflation when there was a shock to CPI inflation and PPI inflation, the response lasted about ten months and then gradually lost. While in the processed food, beverage, cigarette, and tobacco and clothing groups, the response from PPI inflation and CPI inflation when there is a shock to CPI inflation and PPI inflation lasts about six months and then gradually disappears.

The results of IRF analysis indicate that the foodstuffs group has the longest response period compared to the other groups when there is a shock both on PPI inflation and CPI inflation. This can be due to the characteristics of the Indonesian people who are largely dependent on foodstuffs (agricultural products), so that when there is a shock from either the supply side or the demand side, the resulting impact will be longer. While the group of processed food, beverages, cigarettes and tobacco, and clothing group has the shortest response when there is a shock compared to other groups. This IRF result can be seen in Appendix 2.

\section{Variance Decomposition (VD) Analysis}

Variance decomposition (VD) is a VAR model instrument that separates the variance of variables into variable innovation with the assumption that innovation variables are not mutually correlated. Variance decomposition (VD) is performed to characterize the dynamic structure among variables within the VAR model. In other words, VD produces information about the relative importance of each random innovation or how strongly the contribution of the role of a particular variable to other variables in the VAR model (Wulandari, 2007).

Based on the results of Variance Decomposition analysis, it can be seen that the producer price of the foodstuffs group has the greatest contribution in explaining the variation of consumer prices of the foodstuffs group. This is also in line with the IRF analysis showing that the PPI and CPI inflation response when there is a shock to CPI inflation or PPI inflation has 
the longest period. For more details see Appendix 3.

\section{Granger Causality Analysis}

This test is used to find the causality or reciprocal relationship between two variables so that it can be seen whether the two variables are statistically affecting each other (two-way or reciprocal relationship), a one-way relationship, or there is no relationship (not affect each other) (Manik and Hidayat 2010). The results of Granger Causality Test are in the following Table 3.

Table 3 The Result of Granger Causality Test

\begin{tabular}{|c|c|c|c|c|}
\hline Group & Hypothesis $\mathrm{H}_{0}$ & F-Statistics & p-value & Relationship \\
\hline \multirow{3}{*}{ Umum } & PPI_UMUM does not & 3,42369 & $0,0057 * * *$ & PPI Umum $\rightarrow$ \\
\hline & Granger Cause CPI_UMUM & & & \\
\hline & $\begin{array}{l}\text { CPI_UMUM does not } \\
\text { Granger Cause PPI_UMUM }\end{array}$ & 1,85191 & 0,1042 & CPI Umum \\
\hline \multirow[t]{2}{*}{$\mathrm{BM}$} & $\begin{array}{l}\text { PPI_BM does not Granger } \\
\text { Cause CPI_BM }\end{array}$ & 2,23900 & $0,0914 *$ & PPI BM $\leftarrow \rightarrow$ \\
\hline & $\begin{array}{l}\text { CPI_BM does not Granger } \\
\text { Cause PPI_BM }\end{array}$ & 2,25551 & $0,0896^{*}$ & CPI BM \\
\hline \multirow[t]{2}{*}{ MMRT } & $\begin{array}{l}\text { PPI_MMRT does not } \\
\text { Granger Cause CPI_MMRT }\end{array}$ & 0,22516 & 0,7989 & \multirow{2}{*}{$\begin{array}{l}\text { Tidak Ada } \\
\text { Hubungan }\end{array}$} \\
\hline & $\begin{array}{l}\text { CPI_MMRT does not } \\
\text { Granger Cause PPI_MMRT }\end{array}$ & 0,09199 & 0,9122 & \\
\hline \multirow[t]{2}{*}{ SDG } & $\begin{array}{l}\text { PPI_SDG does not Granger } \\
\text { Cause CPI_SDG }\end{array}$ & 1,09318 & 0,3579 & CPI SDG $\rightarrow$ \\
\hline & $\begin{array}{l}\text { CPI_SDG does not Granger } \\
\text { Cause PPI_SDG }\end{array}$ & 3,97756 & $0,0113 * *$ & PPI SDG \\
\hline
\end{tabular}

Table 3 shows that there is a one-way relationship of the general PPI to the general CPI. Whereas the general CPI does not affect the general PPI, which can be seen from its insignificant probability value at $1 \%$ significance level. This shows that consumer price inflation is influenced by producer price inflation. These results imply that general PPI inflation may be a leading indicator of CPI inflation. These results are also consistent with Roger's research in Xin and Yuan (2013), where changes in the price of a raw materials affect the price change of intermediate and final products, as a result, it will affect consumer prices. Therefore, PPI affects $\mathrm{CPI}$, so if there is a shock to producer price, then consumer price will be affected, consequently PPI inflation affects CPI inflation. These results are also consistent with Sidaoui et al. (2009) using Granger's causality analysis found that producer price inflation can serve as a significant tool in predicting consumer price inflation in Mexico.

The PPI group and the foodstuffs CPI have shown a two-way relationship between foodstuffs PPI inflation and foodstuffs CPI inflation at a significance level of $10 \%$. The result means that food price inflation in consumer prices is influenced by food price inflation in producer prices. Similarly, food price inflation in producer prices is influenced by consumer price inflation. This empirical evidence suggests that for the foodstuffs group, PPI inflation may be a leading indicator of CPI inflation and vice versa. That is, changes in producer prices can be an important information in predicting changes in consumer prices and vice versa. This result is consistent with research conducted by Xin and Yuan (2013) which also finds a two-way relationship between PPI and CPI in some countries, i.e. Canada, Denmark, Indonesia, Japan, Pakistan, and Uruguay using Granger causality analysis. 
The two-way relationship between PPI and CPI is also found by Jones in Xin and Yuan (2013) by using Granger analysis, Jones finds a two-way relationship between PPI and CPI in the US. From the supply side, it means that producer price change for foodstuffs group both input price and intermediate input price will affect the price of final products from group of foodstuffs sold to consumers. Conversely, from the demand side, changes in the final demand for foodstuffs group will affect the changes in production costs in producing goods / services that will affect the price of producers.

For clothing group, it is found that there is a one-way relationship from clothing CPI inflation to clothing PPI inflation. The one-way relationship of CPI inflation to PPI inflation for clothing group indicates that in Indonesia clothing inflation is influenced by the demand side. Where changes in demand in the final product will affect the change in input prices as production costs, since the producer's price actually covers the overall cost of production determined by the pull of demand that affects the cost of the resource as it depends on consumer prices (Colclough and Lange 1982). So that shocks to consumer prices will affect the producer price, consequently CPI affect PPI. In other words, CPI inflation can be a leading indicator for PPI inflation, which means that changes in consumer prices for these clothing groups can provide an early indicator for changes in producer price levels. Colclough and Lange (1982) found a one-way relationship of CPI to PPI in the US using Granger causality analysis.

While in the group of processed food, beverages, cigarettes and tobacco, there is no causality relationship between PPI and CPI or vice versa. The absence of a relationship between PPI and CPI inflation for this group could happen when viewed from the graph and the correlation analysis results between the two variables does not indicate a strong relationship. So, for this group, neither the value of PPI or CPI inflation does not influence each other. This result is supported by previous correlation and variance decomposition (VD) analysis results, where the correlation analysis results show that there is no significant relationship between PPI and CPI inflation for processed food, beverage, cigarette and tobacco group. The result of VD analysis also shows that the PPI MMRT variance that explains the variance of CPI MMRT and vice versa is very small, which means that the relationship between the two variables is also weak.

As explained in previous sections, the issue of the relationship between PPI and CPI is still a controversial issue, as there are also studies that do not find any connection between PPI and CPI. As Akcay (2011) using Granger causality analysis found no link between PPI and CPI in the Netherlands and Sweden. In addition, Clark (1995) and Blomberg and Haris (1995) found that PPIs do not significantly affect CPI in the future. Clark (1995) points out that the production chains that link PPI and CPI are weak. PPI changes can sometimes predict CPI changes but fail to systematically predict them.

The existence of the relationship between PPI and CPI both in general and for foodstuffs and clothing groups shows that PPI can be a leading indicator for CPI and vice versa, especially the role of PPI in predicting consumer price inflation. Thus, the government needs to pay more attention to producer prices and make PPI a priority, given that the PPI is currently still releasing on a quarterly basis with 30-day lag.

The role of PPI that can be a leading indicator in predicting consumer price inflation can be one of the important variables for government and policy makers in predicting inflation. While the role of CPI that can be a leading indicator in predicting producer price inflation can also be used by market participants, especially manufacturers in the escalation of contracts. 


\section{CONCLUSIONS AND SUGGESTIONS}

\section{Conclusion}

Based on the results of research that has been done on research entitled Causality Analysis of PPI and CPI in Indonesia then obtained the following conclusion:

1. Through the variance decomposition analysis (VD), the variable that has the greatest variance is the PPI variable of foodstuffs in explaining the variances of the foodstuffs CPI variable, then the general PPI variable in explaining the variances of general CPI variables. While the PPI and CPI variables for the processed food, beverage, cigarette, and tobacco groups, and clothing groups have small variance values in explaining the variance of other variables.

2. Based on the results of Impulse Response analysis, it can be seen that the response of each variable when there is shock to other variables, the average response lasted for six to seven months, then gradually lost.

3. Based on the Granger causality test results, the following results are found:

- General PPI inflation affects the general CPI inflation, so we can conclude that general PPI inflation may be a leading indicator of general CPI inflation.

- Foodstuffs PPI inflation has bidirectional relationship with CPI inflation of foodstuffs so it can be concluded that PPI inflation of foodstuffs group can be a leading indicator for CPI inflation of foodstuffs and vice versa.

- CPI inflation in the clothing group affects the PPI inflation of clothing, which means that CPI inflation of clothing can be a leading indicator for PPI inflation of clothing.

- There is no relationship between PPI inflation and CPI inflation for processed food, beverage, cigarette and tobacco groups.

\section{Suggestion}

Based on the above conclusions, the following suggestions can be drawn:

1. Based on the results of the research, it can be seen that PPI can be a major indicator for CPI, so it is important to make PPI a priority, by releasing PPI data on a monthly basis without any lag.

2. For the government, the information contained in producer prices, can be one important consideration in taking the policy of controlling inflation. As for business actors, information about producer prices can be important information to make decisions in running a business.

3. Looking at the response of PPI and CPI both in general and to each group when shock occurs one of the variables last for an average of 6 to 7 months, then when a shock occurs in one variable (PPI or $\mathrm{CPI}$ ), the government can intervene for the next 6 to 7 months.

4. It is important for the government to always monitor prices both at producer and consumer level, especially for foodstuffs group considering the foodstuffs group has a large contribution to inflation.

\section{REFERENCES}

Akcay S. 2011. The Causal Relationship between Producer Price Index and Consumer Price Index: Empirical Evidence from Selected European Countries. International Journal of Economics and Finance, Vol. 3, No.6; November 2011, www.ccsenet.org/ijef

[BPS] Badan Pusat Statistik. 2015. Panduan Teknis Survei Harga Produsen Tahun 2015. Jakarta (ID) : BPS. 
Blomberg SB, Harris ES. 1995. The Commodity - Consumer Price Connection: Fact or Fable. Federal Reserve Bank of New York Economic Policy Review, v. 1 n. 3.

Caporale GM, Katsimi M, Pittis N. 2002. Causality links between consumer and producer prices: Some empirical evidences. Southern Economic Journal. 68, 703-711.

Chowdury A. 2014. Inflation and inflationuncertainty in India: the policy implications of the relationship. Department of Economics, Marquette University, Milwaukee, Wisconsin, USA Journal of Economic Studies. Vol. 41 No. 1, 2014

Clark T. 1995. Do Producer Prices Lead Consumer Prices?. Federal Reserve Bank of Kansas City Economic Review. Vol. 80, pp. 25-39.

Colclough WG, Lange MD. 1982. Empirical evidence of causality from consumer to wholesale prices. Journal of Econometrics, 19, 379384.

Cushing MJ, McGarvey MG. 1990. Feedback between wholesale and consumer price inflation: A reexamination of the evidence. Southern Economic Journal, 56, 1059-1072.

Enders W. 2004. Applied Econometrics Time Series, Second edition, John Wiley \& Sony Inc.

Galodikwe IK. 2014. Exploring the Relationship Between Producer Price Index and Consumer Price Index in South Africa [Dissertation]. North West University.

Ghazali MF, Yee OA, Zulkifli MM. (2008). Do Producer Prices Cause Consumer Prices? Some Empirical
Evidence. International Journal of Business and Management, 3, 11, 78-82.

Gujarati DN, Porter D. 2009. Basic Econometrics, Fifth edition. McGraw Hill International

Jones JD. 1986. Consumer Prices, Wholesale Prices, and Causality (More Empirical Evidence for the U.S., 1947-198). Empirical Economics, vol. 11, issue 1, pp. 4155.

Manik RES, Hidayat P. 2010. Analisis Kausalitas Antara Pengeluaran Pemerintah dan Pertumbuhan Ekonomi Sumatera Utara. Jurnal Keuangan dan Bisnis Vol.2 No.1 Maret, 2010.

Mankiw N Gregory. 2006. Makroekonomi. Edisi ke-6. Jakarta (ID): Erlangga

Shahbaz M, Tiwari AK, Tahir MI. 2012. Does CPI Granger-Cause WPI?, New Extensions from Frequency Domain Approach in Pakistan, COMSATS Institude of Information Technology, Lahore, Pakistan, ICF AI University, Tripura, GIFT University, Pakistan

Sidaoui JCC, Chiquiar D, Ramos MF. 2009. A note on the predictive content of PPI over CPI inflation: The case of Mexico. Working Paper 2009-14, Banco de Mexico.

Ulke V, Ergun U. 2014. The Relationship between Consumer Price and Producer Price Indices in Turkey. International Journal of Academic Research in Economics and Management Sciences January 2014, Vol. 3, No. 1 ISSN: 22263624, JEL Classification: C32, E31

Utari GAD, et al. 2015. Inflasi di Indonesia Karakteristik dan Pengendaliannya, Seri Kebanksentralan No.23, Bank Indonesia. 
Widarjono A. 2016. Ekonometrika Pengantar dan Aplikasinya Disertai Panduan Eviews Edisi Keempat. Yogyakarta : UPP STIM YKPN.

Yin WK, Xuan JL. 2013. Threshold Cointegration and Causality between CPI and PPiin Selected Countries-Some International Evidence. Working Paper Series
August 2013, Department of Economics and Finance Hong Kong Shue Yan University 48

Wulandari H. 2007. Peranan Volatilitas Nilai Tukar dan Indeks Saham Amerika Serikat dan Jepang terhadap Indeks Saham di ASEAN5 [Skripsi]. Jakarta (ID) : Sekolah Tinggi Ilmu Statistik. 


\section{Appendix 1 Empirical Framework}

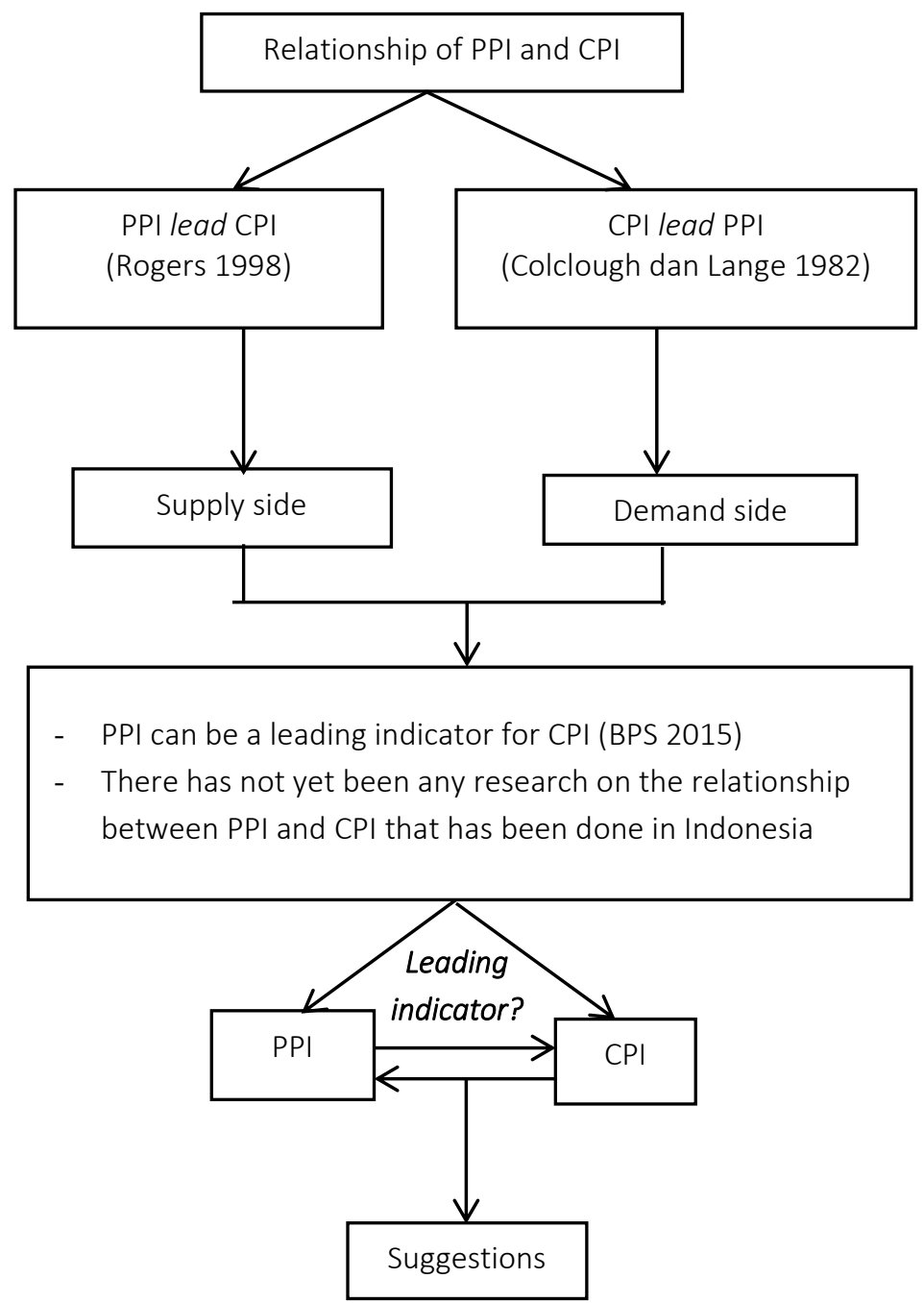




\section{Appendix 2 Impulse Response Function (IRF)}

\section{a. General PPI and General CPI}

Response to Cholesky One S.D. Innovations \pm 2 S.E.

Response of IHP_UMUM to IHP_UMUM

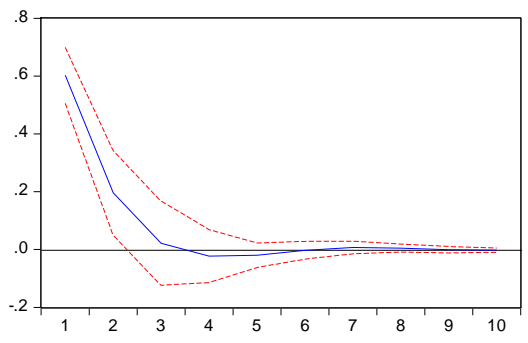

Response of IHK_UMUM to IHP_UMUM

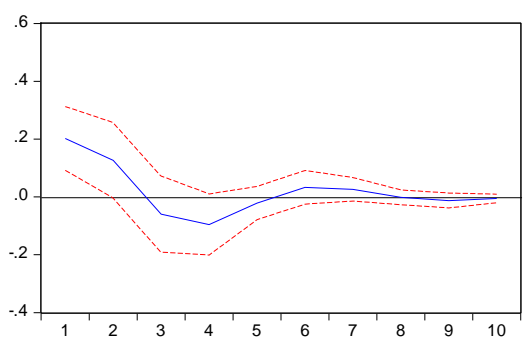

Response of IHP_UMUM to IHK_UMUM

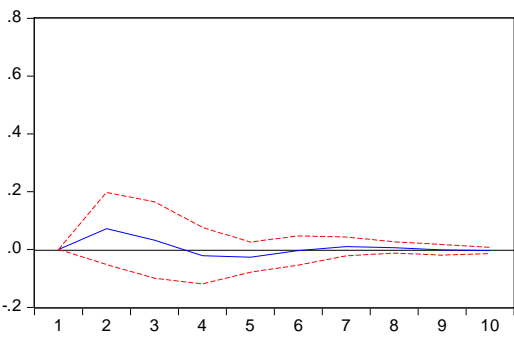

Response of IHK_UMUM to IHK_UMUM

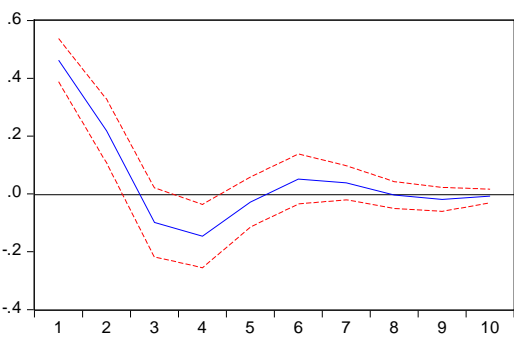

b. PPI of Foodstuffs and CPI Foodstuffs

Response to Cholesky One S.D. Innovations \pm 2 S.E.

Response of IHP_BM to IHP_BM

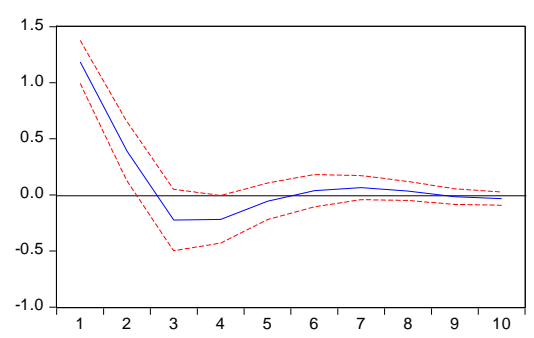

Response of IHK_BM to IHP_BM

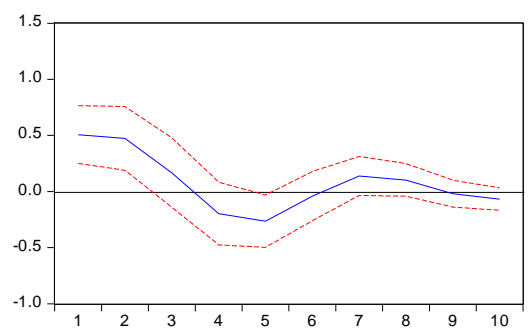

Response of IHP_BM to IHK_BM

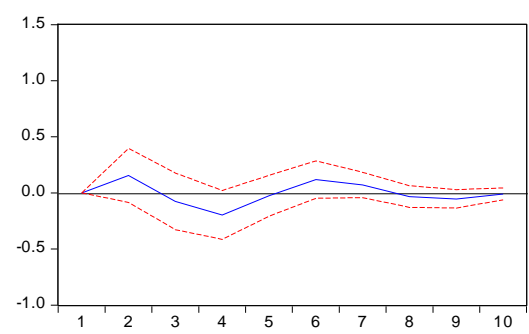

Response of IHK_BM to IHK_BM

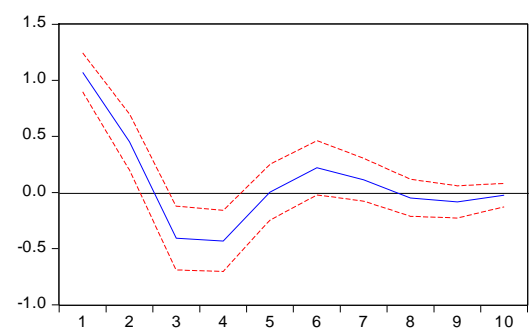


c. PPI and CPI of Processed Food, Beverages, Cigarette, and Tobacco Response to Cholesky One S.D. Innovations \pm 2 S.E.

Response of IHP MMRT to IHP MMRT

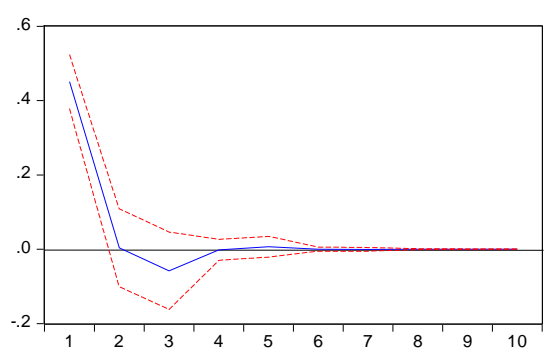

Response of IHK_MMRT to IHP_MMRT

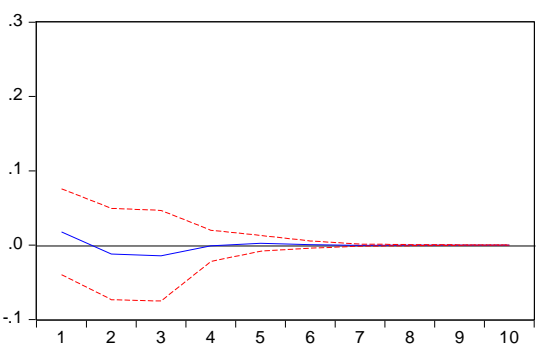

Response of IHP MMRT to IHK MMRT

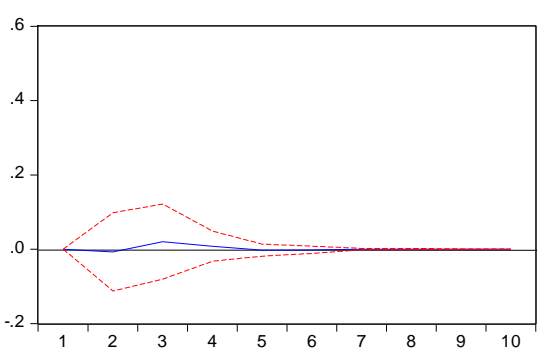

Response of IHK_MMRT to IHK_MMRT

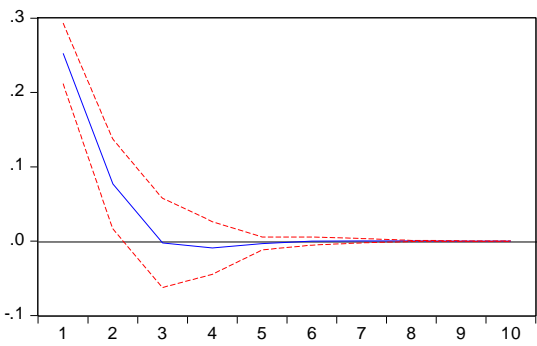

\section{d. PPI and CPI of Clothing}

Response to Cholesky One S.D. Innovations \pm 2 S.E.

Response of IHP_SDG to IHP_SDG

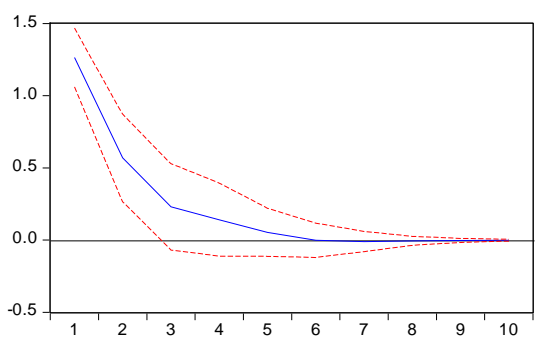

Response of IHK_SDG to IHP_SDG

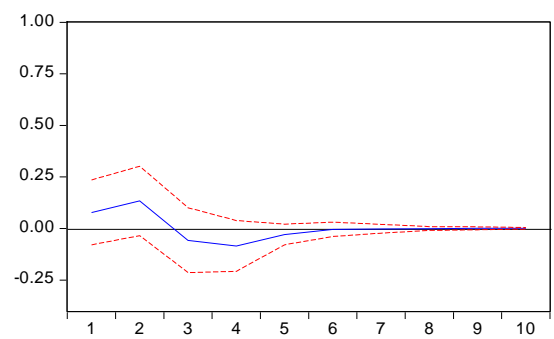

Response of IHP_SDG to IHK_SDG

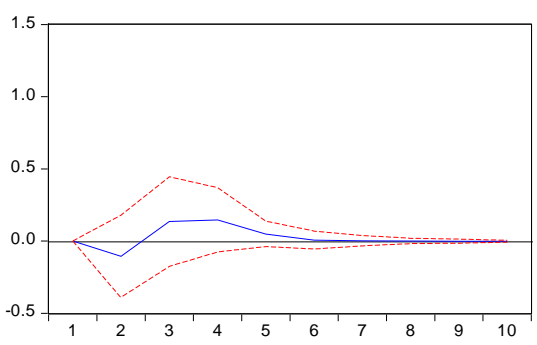

Response of IHK_SDG to IHK_SDG

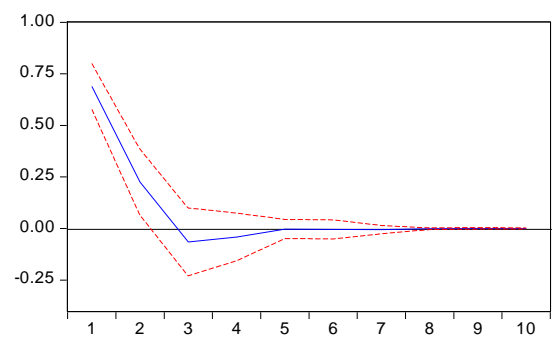




\section{Appendix 3 Variance Decomposition (VD)}

\section{a. General Group}

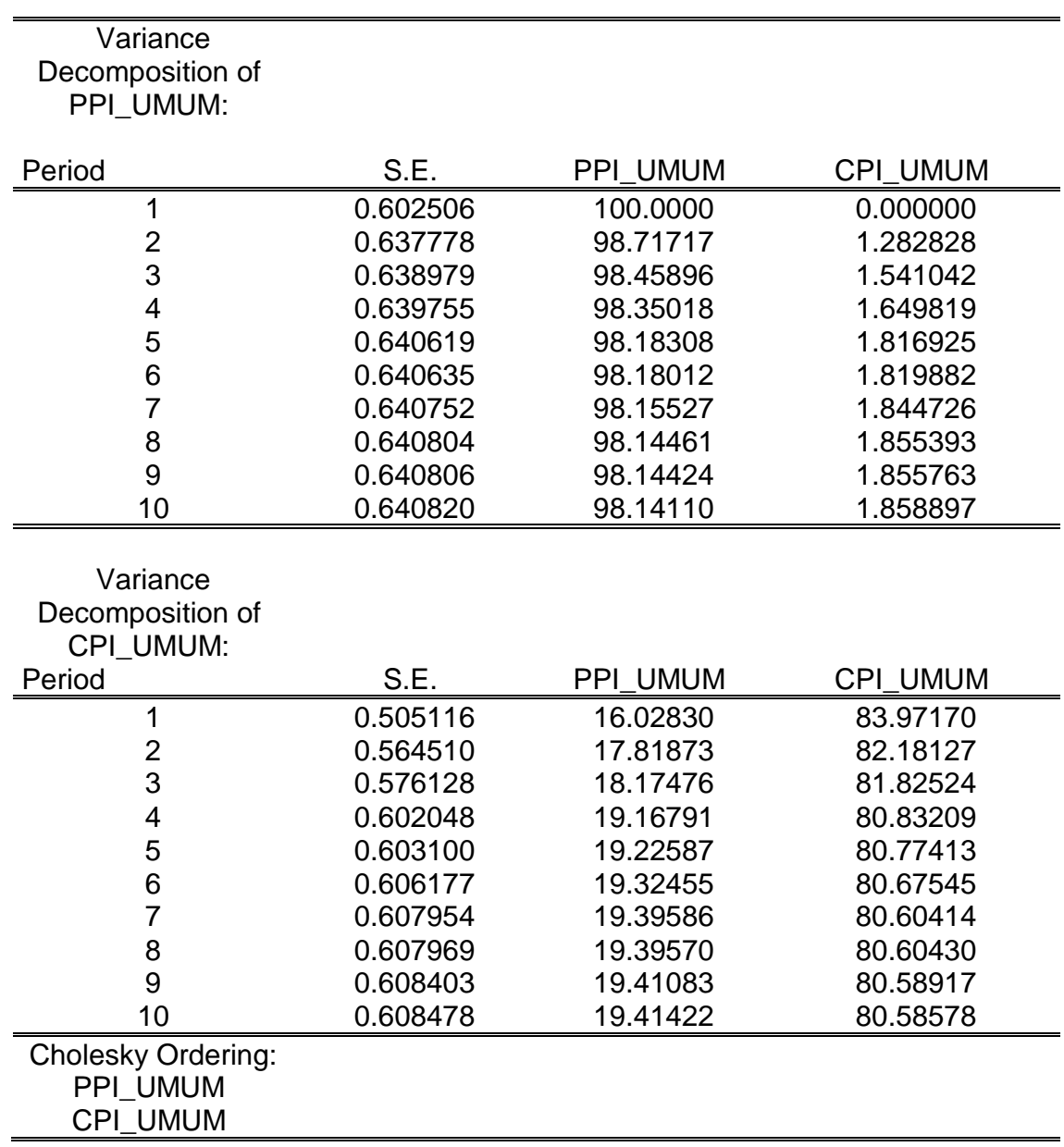




\section{b. Foodstuffs Group}

\begin{tabular}{|c|c|c|c|}
\hline \multicolumn{4}{|l|}{$\begin{array}{c}\text { Variance } \\
\text { Decomposition of } \\
\text { PPI_BM: }\end{array}$} \\
\hline Period & S.E. & PPI_BM & CPI BM \\
\hline 1 & 1.185720 & 100.0000 & 0.000000 \\
\hline 2 & 1.258253 & 98.47029 & 1.529709 \\
\hline 3 & 1.280194 & 98.17556 & 1.824439 \\
\hline 4 & 1.313665 & 96.00888 & 3.991116 \\
\hline 5 & 1.315181 & 95.97757 & 4.022427 \\
\hline 6 & 1.321059 & 95.20446 & 4.795536 \\
\hline 7 & 1.324479 & 94.94753 & 5.052468 \\
\hline 8 & 1.325351 & 94.89058 & 5.109420 \\
\hline 9 & 1.326540 & 94.73537 & 5.264628 \\
\hline 10 & 1.327007 & 94.73388 & 5.266122 \\
\hline \multicolumn{4}{|l|}{$\begin{array}{l}\text { Variance } \\
\text { Decomposition of } \\
\text { CPI_BM: }\end{array}$} \\
\hline Period & S.E. & PPI_BM & CPI_BM \\
\hline 1 & 1.184915 & 18.28561 & 81.71439 \\
\hline 2 & 1.353862 & 26.20672 & 73.79328 \\
\hline 3 & 1.423573 & 25.09382 & 74.90618 \\
\hline 4 & 1.500699 & 24.30350 & 75.69650 \\
\hline 5 & 1.523814 & 26.58229 & 73.41771 \\
\hline 6 & 1.540209 & 26.09224 & 73.90776 \\
\hline 7 & 1.550517 & 26.53664 & 73.46336 \\
\hline 8 & 1.554659 & 26.83020 & 73.16980 \\
\hline 9 & 1.557063 & 26.76501 & 73.23499 \\
\hline 10 & 1.558706 & 26.89608 & 73.10392 \\
\hline $\begin{array}{c}\text { Cholesky Ordering: } \\
\text { PPI_BM } \\
\text { CPI_BM }\end{array}$ & & & \\
\hline
\end{tabular}

c. Processed Food, Beverages, Cigarette, and Tobacco Group

\begin{tabular}{cccc}
\hline \hline $\begin{array}{c}\text { Variance } \\
\text { Decomposition of } \\
\text { PPI_MMRT: }\end{array}$ & S.E. & PPI_MMRT & CPI_MMRT \\
Period & 0.451108 & 100.0000 & 0.000000 \\
\hline 1 & 0.451179 & 99.97475 & 0.025250 \\
2 & 0.455370 & 99.77657 & 0.223433 \\
3 & 0.455445 & 99.74531 & 0.254695 \\
4 & 0.455498 & 99.74214 & 0.257862 \\
5 & 0.455502 & 99.74052 & 0.259484 \\
6 & 0.455503 & 99.74052 & 0.259484 \\
7 & 0.455503 & 99.74049 & 0.259508 \\
8 & 0.455503 & 99.74049 & 0.259509 \\
9 & 0.455503 & 99.74049 & 0.259509 \\
10 & &
\end{tabular}




\begin{tabular}{cccc}
\hline \hline $\begin{array}{c}\text { Variance } \\
\text { Decomposition of } \\
\text { CPI_MMRT: }\end{array}$ & S.E. & PPI_MMRT & CPI_MMRT \\
\hline \hline & & & \\
Period & 0.253446 & 0.494301 & 99.50570 \\
1 & 0.265126 & 0.659278 & 99.34072 \\
2 & 0.265532 & 0.953915 & 99.04609 \\
3 & 0.265697 & 0.954040 & 99.04596 \\
4 & 0.265728 & 0.961984 & 99.03802 \\
5 & 0.265729 & 0.962506 & 99.03749 \\
6 & 0.265729 & 0.962557 & 99.03744 \\
7 & 0.265729 & 0.962570 & 99.03743 \\
8 & 0.265729 & 0.962570 & 99.03743 \\
9 & 0.265729 & 0.962570 & 99.03743 \\
10 & & & \\
\hline \hline Cholesky Ordering: & & & \\
PPI_MMRT & & & \\
CPI_MMRT & & & \\
\hline \hline
\end{tabular}

\section{d. Clothing Group}

\begin{tabular}{|c|c|c|c|}
\hline \multicolumn{4}{|l|}{$\begin{array}{c}\text { Variance } \\
\text { Decomposition of } \\
\text { PPI SDG: }\end{array}$} \\
\hline Period & S.E. & PPI_SDG & CPI_SDG \\
\hline 1 & 1.264457 & 100.0000 & 0.000000 \\
\hline 2 & 1.390383 & 99.42237 & 0.577632 \\
\hline 3 & 1.415658 & 98.53573 & 1.464266 \\
\hline 4 & 1.430081 & 97.52261 & 2.477386 \\
\hline 5 & 1.431896 & 97.41213 & 2.587873 \\
\hline 6 & 1.431910 & 97.41047 & 2.589528 \\
\hline 7 & 1.431953 & 97.41057 & 2.589433 \\
\hline 8 & 1.431966 & 97.41061 & 2.589390 \\
\hline 9 & 1.431970 & 97.41048 & 2.589519 \\
\hline 10 & 1.431971 & 97.41040 & 2.589599 \\
\hline \multicolumn{4}{|l|}{$\begin{array}{l}\text { Variance } \\
\text { Decomposition of } \\
\text { CPI_SDG: }\end{array}$} \\
\hline Period & S.E. & PPI_SDG & CPI_SDG \\
\hline 1 & 0.693941 & 1.259401 & 98.74060 \\
\hline 2 & 0.741709 & 4.340281 & 95.65972 \\
\hline 3 & 0.746768 & 4.871067 & 95.12893 \\
\hline 4 & 0.752685 & 6.065565 & 93.93443 \\
\hline 5 & 0.753266 & 6.208873 & 93.79113 \\
\hline 6 & 0.753292 & 6.211424 & 93.78858 \\
\hline 7 & 0.753315 & 6.211502 & 93.78850 \\
\hline 8 & 0.753317 & 6.211517 & 93.78848 \\
\hline 9 & 0.753317 & 6.211622 & 93.78838 \\
\hline 10 & 0.753318 & 6.211714 & 93.78829 \\
\hline $\begin{array}{c}\text { Cholesky Ordering: } \\
\text { PPI_SDG } \\
\text { CPI_SDG }\end{array}$ & & & \\
\hline
\end{tabular}

